RESEARCH ARTICLE

\title{
Towards a More Robust, but Limited and Contingent Defence of the Political Uses of Deliberative Minipublics
}

\author{
André Bächtiger and Saskia Goldberg
}

The political uses of minipublics confront us with a dilemma: if we accept Cristina Lafont's critique that minipublics should not have direct political traction but only yield a deliberation-promotion function in the public sphere, we are confronted by the fact that this function is muted in our mediatized, partisan and increasingly polarized political societies. To solve this dilemma, we propose an enhanced shortcut approach with semi-blind deference and an appreciation of citizen heterogeneity. We argue that minipublic recommendations can provide trustworthy signals to (some) citizens in the form of recommendations rather than being major contributors to or shapers of public discourse in the form of reasons. We also propose that deference to minipublic recommendations should hinge on four conditions, namely issue type, opinion strength, the direction of minipublic recommendation (confirming or disconfirming one's previously held opinions) and the level of consensus reached by the minipublic. Depending on the configuration of these conditions, semi-blind deference asks citizens (especially those who are basically interested in minipublic recommendations) to search for additional and independent sources and engage with arguments produced by the minipublic. Finally, we claim that diverse sectors of the citizenry might have different utility and trust assessments of minipublic recommendations.

Keywords: minipublics; deliberation; democracy; deference; citizenship; participatory

\begin{abstract}
Introduction
Much hope and effort has been placed in the deployment of deliberative minipublics for the renewal of democratic systems. And in current times of 'democratic crisis' when politics-as-usual seems to be unable to fix the big issues, minipublics are frequently advocated as an effective tool to overcome this crisis. At the same time, deliberative minipublics have been criticized as being disconnected from mass democracy (Chambers 2009; Parkinson 2006). Cristina Lafont has carried this critique further by claiming that the growing use of deliberative minipublics may decrease rather than increase democratic legitimacy. On Lafont's account, deliberative minipublics reach conclusions for reasons that most citizens are not likely to accept: "many [non-deliberating citizens] will find out that the majority of the sample is not like them, since they actually oppose their view, values and policy objectives on the issue in question' (2019: 116). If minipublics were to be directly consequential for policy-making or were authorized to make binding decisions, then the ideal of democratic self-government would be violated. In an update of her critique, Lafont (2019) suggests that deliberative minipublics might still produce 'added value'
\end{abstract}

University of Stuttgart, DE

Corresponding author: André Bächtiger

(andre.baechtiger@sowi.uni-stuttgart.de) for a democratic system: they do so when they contest the majority opinion, when they play a vigilant role, or when they anticipate issues (see also Lafont 2017). On this participatory interpretation, deliberative minipublics might be useful for democratic systems by yielding a 'deliberation-promoting' function for the citizenry whereby the recommendations of minipublics are less relevant than the reasoning behind them (Niemeyer 2014; Parkinson 2020). If one accepts Lafont's critique that deliberative minipublics should not have direct political traction in the form of making binding decisions (as many deliberative democrats do), then the deliberationpromoting function of minipublics looks like a viable escape route.

But in our mediatized, partisan and increasingly polarized political landscape, this escape route can turn into a slippery slope quite quickly. We do know that deliberative minipublics usually have very limited public visibility, even when massive public resources are invested. Certainly, some high-profile deliberative events - the British Columbia Citizen Assembly and especially the Irish Citizen Assemblies as well as the French Citizens' Assembly on Climate Change have fared better in terms of public awareness. But even in these cases, the transmission of minipublic recommendations was fairly minimal. Empirical research suggests that non-participants have merely heard that a minipublic took place and may remember the direction 
of its recommendations (see, for example, Warren \& Gastil 2015; Ingham \& Levin 2018). Some have argued that the institutionalization of minipublics will close this visibility gap: as soon as minipublics become a regular part of the democratic machinery (for example, in the form of 'hybrid bicameralism'; see Abizadeh 2020), attention from media, citizens and politicians will follow. While we do not deny that minipublic activities can spark deliberation in the public sphere, there is reason for scepticism: on the one hand, minipublics will always need to compete for public attention with actors that are much better equipped to shape public debate. On the other hand, deliberative principles with a focus on reason and cooperation do not match the demands of our mediatized societies and the oppositional dynamics of the representative system. As Rummens notes, current democratic publics demand a narrative structure with recognizable antagonists and storylines' (2016: 134).

So, if we accept Lafont's critique (and that of others) that the outcomes of deliberative minipublics should not have direct political traction, but are at the same time confronted with the fact that they usually lack broad transmission to the public sphere, what is a productive role of minipublics in a democratic system? ${ }^{1}$ Our starting point is a personal one: we both love minipublics, since in times of growing political polarization they represent one of the few 'resorts' for reasoned and civilized political exchange about pressing policy issues. Moreover, the two of us would not only trust minipublic recommendations but would use them as a shortcut for our own political opinion-formation and decision-making. Yet Lafont argues that as soon as one thinks through her objections to minipublics, this naive love will tumble. In her view, the two of us would blindly defer to a majority of deliberating citizens who are not like us, especially when they have changed their minds. Hence, we would lose 'authorship' in democratic decision-making and give up the ideal of self-government. So are we simply misled in our love for minipublics? We think not, but what is clear is that in light of Lafont's forceful critique, we need a more robust defence of the political uses of minipublics. To be sure, we do not deny the possibility of a deliberationpromoting' function for minipublics. But we propose that there is an alternative and more realistic pathway for minipublic uptake. Drawing from the idea of trust-based uses of minipublics (MacKenzie \& Warren 2012; Warren \& Gastil 2015), we propose an enhanced shortcut approach with semi-blind deference and an appreciation of citizen heterogeneity.

In a nutshell, we argue that minipublic recommendations can provide high quality and trustworthy signals to (some) citizens in the form of recommendations rather than being major contributors to or shapers of public discourse in the form of reasons. Second, we propose that deference to minipublic recommendations should hinge on four conditions, namely issue type, opinion strength, the direction of minipublic recommendation (confirming or disconfirming one's previously held opinions) and the level of consensus reached by the minipublic. Depending on the configuration of these conditions, semi-blind deference asks citizens to search for additional and independent sources and to engage with arguments produced by the minipublic. Third, we claim that diverse sectors of the citizenry might have different utility and trust assessments of minipublic recommendations. Our defence is embedded in a general contingency proviso, arguing that, depending on the responsiveness of a democratic system, minipublic input might not always be necessary for the opinion-formation of citizens.

\section{Sketches of a Robust Defence An enhanced shortcut approach}

Trying to nest minipublics in a participatory approach stipulating that they will serve as a 'resource for macro deliberation' (Lafont 2019: 14) and shape public debate in discernible ways - is questionable given the systemic visibility gap with regard to minipublics in modern democratic systems. A more realistic escape route for a productive use of minipublics is to nest them in an enhanced shortcut approach. Such an approach combines two traditional premises with a new normative standard: 1) the long-standing insight that complex governance systems must rely upon divisions of cognitive labour whereby most citizens lack the time and resources to know much about the merits of policy debates, and where even the most attentive citizens must trust others to make good judgements on their behalf on many issues (Warren \& Gastil 2015); 2) the idea that individuals can productively use heuristics - or mental shortcuts - that do not require much information to make fairly reliable political judgements; in the case of minipublics this means a focus on recommendations rather than reasons, since '[o]utcomes in the form of policy choices are easy to communicate' (Niemeyer \& Jennstal 2018: 336); and 3) 'semi-blind deference' which rethinks deference to minipublic recommendations in more nuanced ways by delineating conditions under which respective uptake retains its democratic character. In short, 'semi-blind' deference does not conceptualize trust-based uptake as suspending judgement in general (since a prior judgement has been made that their interests or values align with those of the trusted agent) but takes an informational perspective and expects individuals to suspend judgement only under specific and clearly delineated conditions.

Regarding a shortcut approach, Lafont is not against taking heuristics or cues in general. The ideal of democratic self-government, she writes, does not require active participation in the sense that all citizens are expected to 'literally be the authors of all the laws to which they are subject' (Lafont 2019: 180). Her participatory ideal is fairly minimal. It not only encompasses passive citizens but also expects citizens to 'defer a lot' to decisions made by others:

Depending on the issue they may be able to use standard heuristics such as relying on the recommendations of groups whose political views they broadly share or experts whose judgments they have reasons to trust. (Lafont 2019: 126) 
Such deference, says Lafont, is not blind (even if incomplete). Democratically viable deference means that citizens have effective and ongoing possibilities to influence the political process and are able to challenge incongruences between proposed policies and their own preferences. According to Lafont, democratic viability is preserved when we defer to groups or persons with whom we generally have congruent views and interests (a point that we will pick up below). Minipublics do not fall under this rubric since citizens cannot be sure whether they would be on the side of the majority of deliberating citizens had they deliberated themselves. Moreover, minipublics lack both accountability and sanctioning mechanisms that make deference democratic (even if citizens disagree with the outcome).

Our approach to minipublics' legitimacy is different: if we accept that shortcuts are necessary in any democratic system - even in the strongest participatory one - then the question is not only whether deference is blind or non-blind in theory, but whether heuristics and cues are of high quality and trustworthy in practice. In short, we need democratic agents who are capable of making informed assessments of the merits and downsides of policy proposals, without congealed partisan or interestbased entanglements, as well as with an eye on the longterm consequences of policies. Following MacKenzie and Warren (2012) and Warren and Gastil (2015), we think that well-designed minipublics represent a democratic agent of this type. By well-designed minipublics we understand forums that are representative of the citizenry, and include the provision of balanced information, expert testimony and oversight by a facilitator. We know from empirical research that minipublics based on such designs fulfil both epistemic and democratic standards. First, ordinary people are capable of high-quality deliberation. Elements such as good reason-giving and respectful listening are present at relatively high levels (Gerber et al. 2018; Neblo et al. 2018). Participants also learn and change their minds, whereby opinion change in well-structured minipublics responds to information as well as to arguments (Esterling et al. 2019; Gerber et al. 2014; Luskin et al. 2002), and is not a product of undesirable group dynamics (such as group polarization) or of the undue influence of advantaged participants (such as highly educated and rhetorically gifted participants). These results have been replicated in many contexts and for different policy issues (see Fishkin 2018). By the same token, minipublics are still novel institutions that raise a host of objections from outsiders (mostly allegations of citizen incompetence and biased decision-making). In order to be trustworthy, citizens must have acquired some knowledge of how minipublics work internally and why they trump other venues in terms of trustworthy input. ${ }^{2}$

But even if citizens are (minimally) aware of the internal workings of minipublics and their capacity for crafting high quality and trustworthy recommendations, this does not eliminate the problem of blind deference raised by Lafont: if citizens simply take up minipublic recommendations without further examination, they renege on their democratic authorship. Therefore, we introduce a new standard dubbed 'semi-blind deference', ${ }^{3}$ stipulating that depending on defined conditions (specified below), citizens should not only update their opinions on information shortcuts but also search for additional (and independent) sources and engage with arguments. To be sure, this does not imply that citizens systematically search for information or intensively weigh pro and con arguments; it implies only that citizens do not blindly trust one source but either look for other sources or find out why that source came to a specific conclusion. As such, semi-blind deference is less concerned with 'truth-tracking' than with robust uptake that preserves the ideal of democratic authorship. Notice that we use the term 'blind' or 'semi-blind deference' mostly in an informational sense, and not in a political sense as Lafont does. A political reading of 'blind deference' asks how likely it is that recommendations or decisions made or recommended by the agent that one is deferring to will be aligned with one's own interests, values and policy objectives; here, we know from the outset that the agent's reasons will coincide with our own. By contrast, an informational reading of 'blind deference' stipulates that there are situations where we lack information about the issues that are recommended or decided by the agent we are deferring to; knowing the reasons behind the recommendation or decision of the agent will help us to preserve our democratic authorship, especially in the case where we are not sure how robust the basic alignment between the agent and our own interests actually is.

To start, uptake from minipublic recommendations hinges on four conditions. A first condition is issue type. We consider three types of issues particularly apt for minipublic input: 1) issues with high degrees of technical complexity as well as issues with long-term effects, such as tax regulations, healthcare systems, genome editing or climate change (see MacKenzie \& Warren 2012); 2) issues with the danger of political collusion, such as reform of electoral systems or MP pension plans, where representatives have vested interests in preserving the status quo or promoting their own interest; and 3) deadlocked issues, such as abortion in Ireland or Brexit in the UK. For all of these issues, the deliberation component of minipublics can help identify a buried 'public will' common ground, or interesting compromise solutions. A second condition is opinion strength. Minipublic input is primarily useful when citizens are uncertain how they should decide, are ambivalent or have not yet formed an opinion on a policy issue. A third condition is the direction of a minipublic recommendation, namely whether this confirms or disconfirms one's pre-existing opinion or belief. A fourth condition is the level of consensus reached by the minipublic, that is, by how many votes the minipublic recommendation is supported.

Connecting these conditions, we identify four constellations wherein uptake from minipublic recommendations will - and should - follow different logics. Regarding uptake, we take some inspiration from a Bayesian framework, assuming that humans are probabilistic beings (Hahn \& Oaksford 2006: 3) 
or 'broadly Bayesians'4 (Tanasoca 2020) and that the recommendation from a minipublic represents another piece of evidence to update our probability to adhere to a specific policy proposal. We also draw from longstanding psychological research that claims that familiar contexts produce habitual behaviour whereas unfamiliar contexts stimulate reasoned and informed consideration (Marcus et al. 2000). Translated to minipublic uptake, we suggest that confirming and disconfirming signals from minipublics might trigger differential reactions whether we engage with alternative sources and arguments behind the recommendations or not. ${ }^{5}$ Notice further that while the rationales in the four constellations are formulated in a general way, they might primarily apply to specific strata of citizens, namely those who are basically interested in minipublic recommendations (even though we do not deny that they can apply to a broad range of citizens); we will have more to say on this matter below.

1) Assume first that a minipublic recommendation confirms one's pre-existing (but not fully formed) opinion on an issue where minipublic input is worthy of consideration and the recommendation comes with a high level of consensus (say 70 per cent). In this constellation, the minipublic recommendation will enhance the degree of confidence ('credence' in Bayesian parlance) that we had in our previously held opinion or belief of being correct. Psychological research also suggests that confirmation of one's previously held opinion is part of habitual behaviour and might not trigger major engagement with other sources or arguments produced by the minipublic. In light of Lafont's critique, this finding has an intriguing normative spin: democratically speaking, there is nothing wrong if we 'blindly' defer to the minipublic recommendation in case of preference alignment with the majority of the minipublic. Since we do not actually oppose their view, values and policy objectives on the issue in question' (Lafont 2019: 116), we hardly lose democratic authorship when we skip further examination of it. Uptake from minipublics under this condition is not fundamentally different from uptake from groups or actors with which we have interests in common. Of course, this might not be the most productive use of minipublic uptake, but it resembles replication in science where a confirmation of a finding - especially when performed by an independent and trusted source - enhances our confidence that this finding holds true.

2) Assume next that a minipublic recommendation challenges one's pre-existing (but not fully formed) opinion on an issue where minipublic input is worthy of consideration and does so with a high level of consensus (say 70 per cent). A Bayesian updating model suggests symmetry in updating, meaning that while confirming evidence will make people more certain of their opinions, disconfirming evidence will make them less sure thereof. A psychological perspective, however, predicts asymmetry in that disconfirming and confirming evidence may trigger different reactions. If the world starts to deviate from our expectations, that is, our fellow citizens in a minipublic - who have taken in information and considered the topic from all sides - see things differently than we do, then this triggers the 'surveillance system' and we start to engage with additional sources and arguments produced by the minipublic (of course, under the condition that we have a basic interest in the latter's recommendation; see next section). Again, this result bears normative significance: since there is a conflict of opinion or interest with the majority of the minipublic in this condition, further engagement is necessary to preserve democratic authorship. ${ }^{6}$ There is a complication, however. The literature on motivated reasoning predicts that while disconfirming evidence may induce people to dedicate more effort to engage with information, this activity is only directed towards discarding the new evidence and leads to polarization of opinions. Many have claimed that motivated reasoning in association with opinion polarization is a sign of biased updating (for example Taber \& Lodge 2006). Consequently, our standard of semiblind deference which asks us to engage more deeply with alternative sources or arguments in the context of disconfirming signals would produce outcomes that are dubious from an epistemic viewpoint. We disagree. First, partisan motivated reasoning may be less prevalent than is commonly assumed and may predominantly affect those having very strong opinions (we will have more to say on this point in the next section). Partisan motivated reasoning also disappears when citizens have accuracy motives (see Druckman 2012). And finally, opinion polarization is not irrational (and is even plausible in Bayesian updating): if people learn different things from obtaining information, polarization is a possible and rational outcome (Druckman \& McGrath 2019; see also Benoit \& Dubra 2014; Steenbergen \& Lavine 2019). Thus, no normative judgement can be made when citizens polarize, change or keep their opinions in the face of a minipublic recommendation that contradicts their previously held opinions. The only criterion that matters for democratically viable uptake under this condition is whether citizens engage with additional sources and arguments produced by the minipublic.

3) The situation is slightly different when we have not formed an opinion (but are interested in the issue) or are ambivalent, that is, we have simultaneous conflicting reactions or feelings regarding an issue at hand. Generally speaking, a minipublic recommendation might enhance our inclination towards a specific policy measure in this constellation, but since there is a potential conflict of opinion or interest with the majority of the forum, the consideration of additional (and independent) sources or engagement with the arguments produced by the minipublic might become necessary. This normative expectation is in line with empirical research on the information strategies of ambivalent persons. As Lavine et al. (2012) demonstrate empirically, such persons 'pause, acquire information, and reflect' before making judgements (whereas univalent persons - even sophisticated ones - simply follow partisan cues). There is one exception, though. As we further detail in the next section, specific types of citizens - especially publicgood-oriented (and delegatory) citizens who have not formed an opinion yet or are ambivalent - may use such 
recommendations almost blindly in the context of the issue types that we have enumerated before. In our view, citizens oriented towards the public good fulfil Lafont's criterion of 'political' alignment between the interests, values and policy objectives and the decisions made by the agent they are deferring to: they value publicgood-oriented decisions, and this is what minipublics tend to deliver. Of course, public-good-oriented and delegatory citizens can never be fully sure whether the minipublic recommendation represents the substantive policy solution they would have picked had they been participants, but since a minipublic functions as their trusted 'interest group' and they have not yet formed an opinion (and they want to remain passive), they can take the minipublic solution as an essential input for their own preference formation, especially when the level of consensus for the solution in the minipublic is high. Clearly - and this is what we mean by 'almost blindly' if the recommendation of the minipublic is surprising or unusual, then more engagement with it becomes necessary.

4) A final constellation involves the case where a minipublic recommendation comes with a low level of consensus (say 52 per cent). As Lafont speculates, this may be the default case when it comes to controversial issues in politics or issues that the majority of the population still does not know much about, for example transgender rights. Under such conditions, a minipublic recommendation might be arbitrary, independent of whether it conforms or challenges one's pre-existing opinions or beliefs. But it may not be useless. As MacKenzie and Warren suggest, highly contentious or split decisions send a signal that citizens should pay closer attention to the issue: they should participate rather than trust' (2012: 110). Clearly, if this situation were the default case, then one might wonder why we should take the costly route of organizing a minipublic. Though far from representing systematic evidence, glancing through the Participedia databank nonetheless provides a first indication that highly contentious decisions do not seem to be the default case. On the contrary, minipublics seem to come up with fairly consensual results (or large majorities) at surprisingly frequent rates, even when issues are polarized. It is an open question why this is the case, especially since consensus or large majorities do not seem to be the product of biased internal processes (as critics of deliberation have argued). But the fact that levels of consensus tend to be high in many minipublics makes this constellation a less important one - and assigns a bigger role to minipublics to act as information shortcuts.

But how realistic is our standard of semi-blind deference after all? Despite some psychological underpinnings, it may still look more like a normative standard than an empirically tested picture of how citizens make up their minds in democracies. We do not have space to go into details here, but there is evidence that using multiple sources for uptake or engaging with arguments may be more frequent than standard theorizing about democratic opinion formation predicts. In a seminal study on decisionmaking in Swiss direct democracy, Colombo (2018) demonstrates that a considerable number of Swiss citizens frequently make their choices based on arguments, not just partisan cues. However, a closer look at the findings shows that argument-based opinion formation does not seem to rest on an intensive engagement with arguments (as expected by semi-blind deference): Swiss citizens simply remember one argument that has influenced their choices. All this is suggestive that our conception of semiblind deference may have some bite in the real world.

Nonetheless, there are two general counter-arguments to trust-based uptake. First, Lafont argues that a quantitative approach to trust is problematic:

It is problematic in its own terms, since trusting cannot be a matter of degree in the context of making binary decisions on whether or not to endorse a specific recommendation. But there is also no easy way to identify the exact level of consensus on a recommendation that should trigger trust. Setting the bar too high (say, close to 95 percent) would make minipublics useless for most relevant (i.e. contested and complex) political issues, whereas setting it too low (say, close to 51 percent), would make trust in minipublics arbitrary and thus dubiously legitimate. (Lafont 2019: 125)

In practice, however, quantitative trust assessments also on binary decisions - might work in straightforward ways. Drawing from a conjoint experiment on legitimacy perceptions of minipublics, we find that participants wanted (binary) recommendations to be made via a clearcut (more than 60 per cent) and not just a close (52 per cent) majority vote; vast majority decisions (90 per cent), by contrast, did not boost legitimacy feelings (see Goldberg 2020). Of course, this finding may be context-dependent, and different societies might have clear expectations regarding what counts as a clear-cut majority. Moreover, one of the authors of this article participates in Swiss direct democracy on exactly such a quantitative (albeit contingent) approach: if a binary decision in a national, regional or local parliament is made by a clear-cut majority (say 70 per cent) - meaning that there is cross-partisan support - then there is no further need to closely engage with the arguments made in parliament. If the vote in parliament is split, however, then this signals partisan conflict and a closer (but not necessarily in-depth) look at the relevant arguments becomes necessary.

Second, Lafont argues that the use of minipublics as 'trusted information proxies' would seem to have an inbuilt status quo bias. Indeed, if ... non-participants do take high levels of agreement as a signal that the judgment in question is not contentious, then the effect of generalizing this trust-based use of minipublics is likely to be a reinforcement of the majority culture. (Lafont 2019: 125)

This is a critical point, to which we have both an empirical and a principled answer. First, in many minipublics, participants' post-deliberative opinions turn out to be 
progressive (more liberal, more immigration friendly, more inclined to protect the environment etc.), even though exceptions exist and more systematic research on this question is clearly necessary. If such progressive recommendations are taken up by other citizens, this challenges rather than consolidates the status quo. Second, regarding our principled answer, let us review once more the conditions under which a minipublic comes to a conclusion with a high level of consensus. If well-designed, this means that a diverse set of people with diverse opinions has critically examined various proposals and arguments. In other words, we have delegated critical thinking to a group with good capabilities to do so in the context of distinctive issues (complex, 'colluded' and deadlocked) where we know that other groups might do so with more bias, or have failed to come up with propositions on how to solve the impasse. A minipublic recommendation in this context is not a reinforcement of the majority culture, but represents a distinctive majority will, one that defends public against partial interests or privileges middle solutions. But exactly because minipublic recommendations represent a distinctive majority will, this might not be the will of all citizens (for example, not the will of those who legitimately defend partial, partisan or minority interests), requiring that we specify for which citizens the minipublic input is actually useful. We will turn back to this issue in the next section.

Summing up, our enhanced shortcut approach resting on semi-blind deference not only seems broadly compatible with the ways in which citizens process political information and make decisions in democracies, it is also democratically viable since it aligns with the ideal of self-government under conditions of scarce resources for politics and governance complexity (Warren \& Gastil 2015). As such, an enhanced shortcut approach is not miles apart from a participatory interpretation of minipublics as advocated by Lafont: it expects citizens to engage with a minipublic recommendation in flexible and smart ways without giving up their democratic authorship. The main difference from a participatory approach is that an enhanced shortcut approach does not expect minipublics to be major contributors to or shapers of public discourse, but concentrates on their recommendations as (recognizable) signals in our competitive, partisan and mediatized democratic publics.

\section{Taking the heterogeneity of citizen preferences seriously}

Having sketched the general contours of an enhanced shortcut approach with semi-blind deference, we now zoom in on some specifics, namely citizen heterogeneity. The starting point here is that Lafont as well as the proponents of trust-based approaches (MacKenzie \& Warren 2012; Warren \& Gastil 2015) adopt a fairly unitary view of the citizenry where citizens, in general, are expected to consider minipublic recommendations as trustworthy shortcuts. Yet empirical research has shown that different strata of citizens may have very different views of how democratic processes should ideally work (Goldberg et al. 2019; Landwehr \& Steiner 2017; Christensen \& von Schoultz 2017). At a general level, citizens either have a strong preference for representative and delegatory schemes or value participatory modes of governance (including minipublics). We argue that different types of citizens may have different preferences regarding the political uses of minipublics as well as different utility and trust assessments of minipublic recommendations. In a nutshell: minipublic recommendations might be very useful for some citizens but not for others. And citizens who find these recommendations useful might also have an incentive to know what a minipublic has recommended or decided.

Our own reflections as authors of this piece resonates with this observation. One of us is a party member while the other is non-partisan and generally prefers delegation to active participation; but we are both deliberative democrats and appreciate political outcomes that are well reflected, moderate and bridge-building across political divides. Overall, the two of us would value minipublics for their outcomes (public-good orientation and moderation) rather than for their selection mechanism (mirror). Thus, the distinctive majority will represented by minipublics might primarily be useful for public-good-oriented and delegatory citizens.

There are other types of citizens who might find minipublic recommendations both useful and trustworthy: dissatisfied democrats and distrustful populists. We know from survey research (for example Bengtsson \& Mattila 2009; Coffé \& Michels 2014; Dalton et al. 2001; Goldberg et al. 2019) that citizens with low external efficacy and low satisfaction with democracy want something else - or something more - from democracy, namely more participatory mechanisms of any type (deliberative minipublics, direct democratic instruments, or combinations of the two). What we do not know, however, is whether this interest in a greater role for minipublics is truly participatory or only delegatory, that is, whether dissatisfied democrats actually want to participate themselves or value participatory innovations by staying passive themselves. ${ }^{7}$ As we argue below, minipublic recommendations will not be useful for dissatisfied democrats with a participatory orientation. Distrustful populists, in turn, might find the mirror conception embedded in (representative) minipublics a crucial point of attraction. The populist ideal stresses the unfiltered will of the people, and everything proposed or decided by ordinary citizens is considered legitimate. However, the mirror element in minipublics disappears at 'the moment a group's opinions start to depart from the distribution found in the general population' (Parkinson 2006: 81). How distrustful populists react to opinion changes in minipublics is an open (empirical) question. An experiment on preferences for direct democracy in Belgium shows that distrustful populists may have strategic considerations when choosing democratic innovations; they hope that their substantive policy preferences might win a majority in the context of such alternative procedures (Werner 2019). Hence, if they see minipublics merely as a strategic means to implement 
their preferred goals (on their account 'corrupted' by legacy institutions), then the legitimacy of minipublic recommendations will wither away quite quickly when a minipublic decides against their own preferences. In a follow-up study, however, Werner and Jacobs (2019) find that populist citizens are not more instrumentally motivated than non-populists. Populist citizens even seem to have more principled views on the legitimacy of referendums and are more willing to accept unfavourable outcomes than non-populist citizens. Extrapolating from this, we might speculate that populist citizens might not only find minipublics attractive because they are mirrors of the 'people', but might also be willing to consider minipublic recommendations that contradict their previously held opinions.

But other types of citizens might not see much value in minipublic input. This applies, for instance, to strongminded partisans and ideologically committed citizens. As we have argued in the last section, minipublic input is hardly productive when we already have clearly formed opinions. On the one hand, if the level of confidence in one's opinion is already very high, then this decreases the marginal utility of recommendations by minipublics that confirm one's previously held opinion. On the other hand, while disconfirming inputs might have some value from an epistemic point of view (Goodin 2003: ch. 7), for strongminded people especially they are hardly guides for belief revision. Thomas Kelly has argued from a philosophical standpoint that, confronted with disconfirming evidence, strong-minded people can always assume that on this particular issue they 'have done a better job with respect to weighing the evidence and competing considerations' than a majority of fellow citizens (Kelly 2005: 16). Notice further that being partisan or ideologically committed is also contingent on the issue at hand. For the two of us, for instance, there are some issues where we are partisan or have very strong opinions; minipublic recommendations that contradict these opinions will hardly induce us to revise them.

Another type of citizens who might discard minipublic input are activist participatory democrats, whose activism might have principled roots or arise from dissatisfaction with current politics. Their democratic ideal involves the conception that the citizenry as a whole should be able to influence or keep control of the political system. For this type of citizen, minipublics should have very limited roles in advising the public. Indeed, our conjoint experiment on legitimacy perceptions of minipublics shows that citizens who generally favour deliberative and participatory procedures clearly prefer a purely advisory role for minipublics (Goldberg 2020).

Our list of citizen types that may find minipublic input productive or unproductive is neither exhaustive nor empirically corroborated. Future research will need to take a more systematic look at who is potentially 'in love' with minipublics, and who is not. And we do not discount that interest in minipublic recommendations (especially when considering specific types of issues, such as 'colluded' ones) might be more widespread in the citizenry than suggested here.

\section{A general contingency proviso}

Throughout this article, we have argued that productive and democratically viable uptake from minipublics depends on conditions as well as on different types of citizens. We now generalize these contingency claims. Our general contingency proviso draws from the recent functional or problem-based turn in theorizing minipublics (Warren 2017; Beauvais \& Warren 2018; Bächtiger \& Parkinson 2019). In this regard, Kuyper and Wolkenstein (2018) have claimed that minipublics should have strong decision-making powers if the representative system is not responsive to citizen concerns. Conversely, if the representative system is basically responsive, then deliberative forums should only have consultative functions. While we might not agree with Kuyper and Wolkenstein's proposal in terms of the strong authorization of minipublics (even under conditions of malfunctioning representative systems), their approach points in the right direction: if a democratic system is not responsive and the public sphere does not provide citizens with good and balanced information, then minipublic input may be crucial. But when a democratic system is basically responsive and entails a healthy public sphere, minipublic input becomes less relevant. Such problembased thinking can be extended to all democratic practices: if specific ends can be reached more efficiently via other institutional pathways, then we might decide to choose these other means rather than using minipublics. For instance, in political systems with properly functioning 'consensus' parliaments, common-good-oriented and delegatory citizens can find useful shortcuts for making political decisions. As empirical research has shown, such institutions both involve a deliberative component and conduce to moderated outcomes (Steiner et al. 2004). In the presence of such an institution, additional input from a minipublic may be more or less a duplication of both the process and outcomes delivered by a 'consensus' parliament. ${ }^{8}$ Nonetheless, all representative institutions - including consensus settings - have collusion moments or are myopic when it comes to long-term interests (MacKenzie 2018). As such, there will always be some demand for minipublic input. Yet from a problem-based or functional perspective, this demand is never universal, but limited in three ways: with regard to issues that are worth being treated by minipublics (in combination with the other conditions specified above, namely opinion strength, the direction of minipublic recommendation and the level of consensus); with regard to their usefulness for different types of citizens; and with regard to the general responsiveness of the democratic system.

\section{Conclusion}

Our limited and contingent defence of minipublics, understanding them as useful and trustworthy 'shortcuts' under specific conditions, will certainly disappoint minipublic promoters and many deliberative democrats. While we do not deny the possibility that minipublics can sometimes exert a deliberation-promoting function in the public sphere (and would greatly welcome this), we think that a participatory vision cannot be the only foundation 
for the political uses of minipublics in our competitive, partisan-structured and mediatized democracies. We must live with the fact that minipublic input will be fairly minimal, primarily providing a cue or heuristic rather than being an object of intensive engagement and consideration in the public sphere. Therefore, an enhanced shortcut approach with semi-blind deference and an appreciation of citizen heterogeneity helps provide more robust foundations for the political uses of minipublics, while simultaneously preserving their democratic viability. To conclude, the age of minipublics is yet to come, but democratically viable uses of minipublics might proceed on two tracks: a fully fledged participatory track (Lafont 2019) where arguments tested or clarified by minipublics affect discussions in the public sphere; or a shortcut track, where specific types of citizens update their policy preferences primarily via minipublic recommendations and engage with minipublic arguments only under specific circumstances. We posit that the second pathway - even though more indirect and admittedly less inspirational - might actually have more bite in the real world.

\section{Notes}

${ }^{1}$ Of course, one might object that minipublics could still serve as policy-consulting devices for political and administrative actors. But this raises a 'secondorder problem' of blind deference: if political authorities directly implement the recommendation of a minipublic without further processing, then they implement or follow a majority will that might not be accepted by non-participating citizens.

${ }^{2}$ For the purpose of this article, we downplay this aspect, for two reasons. First, we do know from survey research that non-participants can actually familiarize themselves with the workings of minipublics (composition and function; see Carty et al. 2009; Warren \& Gastil 2015). Second, some knowledge of the internal workings of minipublics is not only a necessary condition for our enhanced shortcut approach but also for a participatory conception of minipublics as advocated by Lafont. If citizens think that both the process and outcomes of minipublics are flawed, then they would be equally foolish to pick up recommendations from minipublics or to engage with arguments produced by them.

${ }^{3}$ Goodin (2020) also calls this 'partial deference'.

${ }^{4}$ This means that people follow the basic principles of Bayesian updating without employing the precise formula (Tanasoca 2020).

${ }^{5}$ We thank Marco Steenbergen and Ana Tanasoca for helping us to clarify Bayesian updating as well as alerting us to psychological underpinning of our conception of semi-blind deference.

${ }^{6}$ Pettit (2006) has argued that simple (we might also say blind) deference to supermajorities (but not to majorities) is reasonable, since problems such as the 'discursive dilemma' are circumvented in this condition, even in the context of deeply held beliefs. But this would presuppose that participants in a minipublic are 'epistemic peers'. They are not. Even if citizens assume that most of their fellow citizens are 'reasonable', they have no good reason to assume that they share their values, interests, and policy objectives. Certainly, a very high level of consensus in a minipublic can be a strong signal to reconsider one's opinions, but it can never be the sole guide.

${ }^{7}$ We thank Cristina Lafont for highlighting this point.

${ }^{8}$ An example for such 'duplication' is a field experiment in Swiss direct democracy on a highly contested issue, the expulsion initiative of the Swiss People's Party in 2010. This initiative asked for quasi-automatic expulsion of criminal foreigners, and not only involved a populist dimension but also touched upon constitutionally sensitive issues. After deliberating in an online chat, participants were clearly in favour of a compromise counter-proposal worked out by the majority in parliament which tried to align the popular demand for expulsion with the requirements of international and basic law (Bächtiger et al. 2011).

\section{Acknowledgements}

We thank Marco Steenbergen, Ana Tanasoca and the anonymous reviewer for extremely smart as well as generous comments on previous versions of this article. We also thank German Research Foundation (DFG) for funding related empirical research (project number 432370948).

\section{Competing Interests}

The authors have no competing interests to declare.

\section{References}

Abizadeh, A. (2020). Representation, bicameralism, political equality, and sortition: Reconstituting the second chamber as a randomly selected assembly. Perspectives on Politics, 1-16. Online publication. DOI: https://doi.org/10.1017/S1537592719004626

Bächtiger, A., \& Parkinson, J. (2019). Mapping and measuring deliberation: Towards a new deliberative quality. Oxford: Oxford University Press. DOI: https:// doi.org/10.1093/oso/9780199672196.001.0001

Bächtiger, A., Steenbergen, M. R., Gautschi, T., \& Pedrini, S. (2011). Deliberation in Swiss direct democracy: A deliberative field experiment on the expulsion initiative of the Swiss people's party. NCCR Newsletter, 8(5).

Beauvais, E., \& Warren, M. E. (2018). What can deliberative mini-publics contribute to democratic systems? European Journal of Political Research, 58(3), 893-914. DOI: https://doi.org/10.1111/14756765.12303

Bengtsson, A., \& Mattila, M. (2009). Direct democracy and its critics: Support for direct democracy and stealth democracy in Finland. West European Politics, 32(5), 1031-1048. DOI: https://doi. org/10.1080/01402380903065256

Benoit, J.-P., \& Dubra, J. (2014). A theory of rational attitude polarization. Social Sciences Research Network, 1-42. DOI: https://doi.org/10.2139/ssrn.2754316 
Carty, K., Cutler, F., \& Fournier, P. (2009, July 8). Who killed BCSTV? The Tyee.

Chambers, S. (2009). Rhetoric and the public sphere: Has deliberative democracy abandoned mass democracy? Political Theory, 37(3), 323-350. DOI: https://doi. org/10.1177/0090591709332336

Christensen, H. S., \& von Schoultz, A. (2017). Ideology and deliberation: An analysis of public support for deliberative practices in Finland. International Journal of Public Opinion Research, 31(1), 178-194. DOI: https://doi.org/10.1093/ijpor/edx022

Coffé, H., \& Michels, A. (2014). Education and support for representative, direct and stealth democracy. Electoral Studies, 35, 1-11. DOI: https://doi.org/10.1016/j. electstud.2014.03.006

Colombo, C. (2018). Justifications and citizen competence in direct democracy: A multilevel analysis. British Journal of Political Science, 48(3), 787-806. DOI: https://doi.org/10.1017/S0007123416000090

Dalton, R. J., Bürklin, W. P., \& Drummond, A. (2001). Public opinion and direct democracy. Journal of Democracy, 12(4), 141-153. DOI: https://doi. org/10.1353/jod.2001.0066

Druckman, J. N. (2012). The politics of motivation. Critical Review, 24(2), 199-216. DOI: https://doi.org/1 $0.1080 / 08913811.2012 .711022$

Druckman, J. N., \& McGrath, M. C. (2019). The evidence for motivated reasoning in climate change preference formation. Nature Climate Change, 9, 111-119. DOI: https://doi.org/10.1038/s41558-018-0360-1

Esterling, K. M., Fung, A., \& Lee, T. (2019). When deliberation produces persuasion rather than polarization: Measuring and modelling small group dynamics in a field experiment. British Journal of Political Science, 1-19. DOI: https://doi.org/10.1017/ S0007123419000243

Fishkin, J. S. (2018). Democracy when the people are thinking: Revitalizing our politics through public deliberation. Oxford: Oxford University Press. DOI: https://doi. org/10.1093/oso/9780198820291.001.0001

Gerber, M., Bächtiger, A., Fiket, I., Steenbergen, M., \& Steiner, J. (2014). Deliberative and non-deliberative persuasion: Mechanisms of opinion formation in EuroPolis. European Union Politics, 15(3), 410-429. DOI: https://doi.org/10.1177/1465116514528757

Gerber, M., Bächtiger, A., Shikano, S., Reber, S., \& Rohr, S. (2018). Deliberative abilities and deliberative influence in a transnational deliberative poll (EuroPolis). British Journal of Political Science, 48(4), 1093-1118. DOI: https://doi.org/10.1017/ S0007123416000144

Goldberg, S. (2020). Just advisory and maximally representative: A conjoint experiment on how nonparticipants evaluate deliberative forums. Unpublished manuscript.

Goldberg, S., Wyss, D., \& Bächtiger, A. (2019). Deliberating or thinking (twice) about democratic preferences: What German citizens want from democracy. Political Studies, 68(2), 311-331. DOI: https://doi.org/10.1177/0032321719843967
Goodin, R. E. (2003). Reflective democracy. Oxford: Oxford University Press. DOI: https://doi. org/10.1093/0199256179.001.0001

Goodin, R. E. (2020) Between full endorsement and blind deference. Journal of Deliberative Democracy, 16(2), 25-32. DOI: https://doi.org/10.16997/jdd.393

Hahn, U., \& Oaksford, M. (2006). A Bayesian approach to informal argument fallacies. Synthese, 152, 207-236. DOI: https://doi.org/10.1007/s11229-005-5233-2

Ingham, S., \& Levin, I. (2018). Effects of deliberative minipublics on public opinion: Experimental evidence from a survey on social security reform. International Journal of Public Opinion Research, 30(1), 51-78. DOI: https://doi.org/10.1093/ijpor/edw030

Kelly, T. (2005). Moorean facts and belief revision, or can the skeptic win? Philosophical Perspectives, 19(1), 179-209. DOI: https://doi.org/10.1111/j.15208583.2005.00059.x

Kuyper, J., \& Wolkenstein, F. (2018). Complementing and correcting representative institutions: When and how to use mini-publics. European Journal of Political Research, 1-20. DOI: https://doi.org/10.1111/14756765.12306

Lafont, C. (2017). Can democracy be deliberative and participatory? The democratic case for political uses of mini-publics. Daedalus, 146(3), 85-105. DOI: https:// doi.org/10.1162/DAED_a_00449

Lafont, C. (2019). Democracy without shortcuts: A participatory conception of deliberative democracy. Oxford: Oxford University Press. DOI: https://doi. org/10.1093/oso/9780198848189.001.0001

Landwehr, C., \& Steiner, N. D. (2017). Where democrats disagree: Citizens' normative conceptions of democracy. Political Studies, 65(4), 786-804. DOI: https://doi.org/10.1177/0032321717715398

Lavine, H. G., Johnston, C. D., \& Steenbergen, M. R. (2012). The ambivalent partisan: How critical loyalty promotes democracy. Oxford: Oxford University Press. DOI: https://doi.org/10.1093/acprof: oso/9780199772759.001.0001

Luskin, R. C., Fishkin, J. S., \& Jowell, R. (2002). Considered opinions: Deliberative polling in Britain. British Journal of Political Science, 32(3), 455-487. DOI: https://doi.org/10.1017/S0007123402000194

MacKenzie, M. K. (2018). Deliberation and long term decisions: Representing future generations. In A. Bächtiger, J. S. Dryzek, J. Mansbridge \& M. E. Warren (Eds.), The Oxford handbook of deliberative democracy (pp. 251-272). Oxford: Oxford University Press. DOI: https://doi.org/10.1093/ oxfordhb/9780198747369.013.7

MacKenzie, M. K., \& Warren, M. E. (2012). Two trustbased uses of minipublics in democratic systems. In J. Mansbridge \& J. Parkinson (Eds.), Deliberative systems (pp. 95-124). Cambridge: Cambridge University Press. DOI: https://doi.org/10.1017/ CBO9781139178914.006

Marcus, G. E., Neuman, W. R., \& MacKuen, M. (2000). Affective intelligence and political judgment. Chicago, IL: University of Chicago Press. 
Neblo, M. A., Esterling, K. M., \& Lazer, D. M. J. (2018). Politics with the people: Building a directly representative democracy. Cambridge: Cambridge University Press. DOI: https://doi.org/10.1017/9781316338179

Niemeyer, S. (2014). Scaling up deliberation to mass publics: Harnessing minipublics in a deliberative system. In K. Grönlund, A. Bächtiger \& M. Setälä (Eds.), Deliberative mini-publics: Practices, promises, pitfalls (pp. 177-201). London: Rowman \& Littlefield.

Niemeyer, S. J., \& Jennstal, J. (2018). Scaling up deliberative effects - applying lessons of mini-publics. In A. Bächtiger, J. S. Dryzek, J. Mansbridge \& M. E. Warren (Eds.), The Oxford handbook of deliberative democracy (pp. 329347). Oxford: Oxford University Press. DOI: https://doi. org/10.1093/oxfordhb/9780198747369.013.31

Parkinson, J. (2006). Deliberating in the real world: Problems of legitimacy in deliberative democracy. Oxford: Oxford University Press. DOI: https://doi. org/10.1093/019929111X.001.0001

Parkinson, J. (2020). The roles of referendums in deliberative systems. Representation. Online publication. DOI: https://doi.org/10.1080/00344893.2020.1718195

Pettit, P. (2006). When to defer to majority testimony and when not. Analysis, 66(291), 179-87. DOI: https:// doi.org/10.1111/j.1467-8284.2006.00612.x

Rummens, S. (2016). Legitimacy without visibility? On the role of mini-publics in the democratic system. In M. Reuchamps \& J. Suiter (Eds.), Constitutional deliberative democracy in Europe (pp. 129-146). Colchester: ECPR Press.

Steenbergen, M. R., \& Lavine, H. (2019). Belief change: A Bayesian perspective. In H. Lavine \& C. S. Taber
(Eds.), The feeling, thinking citizen: Essays in honor of Milton Lodge (pp. 99-124). New York: Routledge. DOI: https://doi.org/10.4324/9781351215947

Steiner, J., Bächtiger A., Spörndli, M., \& Steenbergen M. R. (2004). Deliberative politics in action: Analysing parliamentary discourse. Cambridge: Cambridge University Press. DOI: https://doi.org/10.1017/ CBO9780511491153

Taber, C. S., \& Lodge, M. (2006). Motivated skepticism in the evaluation of political beliefs. American Journal of Political Science, 50(3), 755-769. DOI: https://doi. org/10.1111/j.1540-5907.2006.00214.x

Tanasoca, A. (2020). Deliberation naturalized: Improving real-existing deliberative democracy. Oxford: Oxford University Press. Forthcoming

Warren, M. E. (2017). A problem-based approach to democratic theory. American Political Science Review, 111(1), 39-53. DOI: https://doi.org/10.1017/ S0003055416000605

Warren, M. E., \& Gastil, J. (2015). Can deliberative minipublics address the cognitive challenges of democratic citizenship? The Journal of Politics, 77(2), 562-574. DOI: https://doi.org/10.1086/680078

Werner, H. (2019). If I'll win it, I want it: The role of instrumental considerations in explaining public support for decision-making through referendums. European Journal of Political Research. DOI: https:// doi.org/10.1111/1475-6765.12358

Werner, H., \& Jacobs, K. (2019, September). Are populists sore losers? Explaining populist citizens' preferences for and reactions to referendums. Paper presented at the ECPR General Conference, Wroclaw, Poland.

How to cite this article: Bächtiger, A., \& Goldberg, S. (2020). Towards a More Robust, but Limited and Contingent Defence of the Political Uses of Deliberative Minipublics. Journal of Deliberative Democracy, 16(2), pp. 33-42. DOI: https://doi.org/10.16997/jdd.390

Submitted: 10 June $2020 \quad$ Accepted: 08 July 2020 Published: 14 October 2020

Copyright: ( $) 2020$ The Author(s). This is an open-access article distributed under the terms of the Creative Commons Attribution 4.0 International License (CC-BY 4.0), which permits unrestricted use, distribution, and reproduction in any medium, provided the original author and source are credited. See http://creativecommons.org/licenses/by/4.0/. 